\title{
LONG-TERM POPULATION TRENDS OF COLONIAL WADING BIRDS BREEDING IN DOÑANA (SW SPAIN) IN RELATION TO ENVIRONMENTAL AND ANTHROPOGENIC FACTORS
}

\author{
TENDENCIAS POBLACIONALES A LARGO PLAZO \\ DE LAS AVES ZANCUDAS COLONIALES QUE NIDIFICAN \\ EN DOÑANA (SO DE ESPAÑA) EN RELACIÓN \\ CON LOS FACTORES AMBIENTALES Y ANTRÓPICOS
}

\author{
Cristina RAMO ${ }^{1}$ *, Eduardo AguilerA ${ }^{2}$, Jordi Figuerola ${ }^{1}$, \\ Manuel MÁÑEz ${ }^{3}$ and Andy J. GREEN ${ }^{1}$
}

\begin{abstract}
SumMARY.-Breeding season counts of nine species of colonial wading birds (Nycticorax nycticorax, Ardeola ralloides, Bubulcus ibis, Egretta garzetta, Ardea cinerea, Ardea purpurea, Ciconia ciconia, Plegadis falcinellus and Platalea leucorodia) nesting at Doñana during 1984-2010 were analysed. The aim of the study was to assess the size and trends of populations and to analyse their environmental and anthropogenic determinants. We used the TRIM programme to test for long-term trends, and Generalised Additive Models to assess the effect of local rainfall, the surface area of ricefields surrounding Doñana and rainfall in the Sahel on breeding population size. All species showed positive population trends, mainly from 1996 onwards. The number of active colonies increased over time, and up to 17,297 nests from the nine studied species were recorded in one year (2010). Low precipitation $(<500 \mathrm{~mm})$ in the previous autumn and winter was associated with reductions in the numbers of breeders, since rainfall determines the flooding extent in the natural marshes of Doñana. The area of ricefields positively influenced the breeding numbers of five species. Only four of these species are considered to be increasing in Europe and increases in Doñana coincide with management changes that have improved nesting and feeding habitat and reduced human disturbance. In addition to large-scale man-made habitat changes, breeding population sizes for the studied species were strongly influenced by high annual variation in rainfall, typical of Mediterranean habitats, therefore making them likely to be affected by climate change.
\end{abstract}

Key words: Doñana, egret, habitat changes, heron, ibis, nesting, spoonbill, stork.

1 Department of Wetland Ecology, Estación Biológica de Doñana (EBD-CSIC), c/ Américo Vespucio s/n, 41092 Seville, Spain.

2 Department of Ethology and Biodiversity Conservation, Estación Biológica de Doñana (EBD-CSIC), c/ Américo Vespucio s/n, 41092 Seville, Spain.

3 Natural Processes Monitoring Team, Estación Biológica de Doñana (EBD-CSIC), c/ Américo Vespucio s/n, 41092 Seville, Spain.

* Corresponding autor: cristina@ebd.csic.es 
RESUMEN. - En este trabajo se analizan los censos de la población reproductora de nueve especies de aves zancudas coloniales (Nycticorax nycticorax, Ardeola ralloides, Bubulcus ibis, Egretta garzetta, Ardea cinerea, Ardea purpurea, Ciconia ciconia, Plegadis falcinellus y Platalea leucorodia) en Doñana durante el periodo 1984-2010. El propósito del estudio fue evaluar el tamaño y la tendencia de las poblaciones y analizar su relación con los factores ambientales y antrópicos. Se utilizó el programa TRIM para calcular las tendencias a largo plazo, y los modelos aditivos generalizados (GAMs) para evaluar el efecto de la precipitación local, la superficie de arrozal que rodea a Doñana, y la precipitación en el Sahel sobre el tamaño de la población reproductora. Todas las especies mostraron tendencias poblacionales positivas, especialmente desde 1996. El número de colonias activas aumentó con el tiempo, llegando a contabilizarse 17.297 nidos de las nueve especies en 2010. Precipitaciones por debajo de los $500 \mathrm{~mm}$ durante el otoño e invierno precedentes se asociaron con reducciones en el número de reproductores, ya que las precipitaciones determinan la extensión de la inundación en las marismas naturales de Doñana. La superficie de arrozal influenció positivamente el número de parejas reproductoras de 5 especies. Sólo las poblaciones de 4 de las especies estudiadas están incrementándose en Europa, y los aumentos en Doñana coinciden con cambios en la gestión que han mejorado los hábitats de nidificación y de alimentación, y han reducido las molestias por parte del hombre. El tamaño de la población reproductora de las especies estudiadas estuvo fuertemente influenciado por la gran variación anual en las precipitaciones, típica de los hábitats mediterráneos, y probablemente se verá afectado por el cambio climático.

Palabras clave: Doñana, cambios en el hábitat, cigüeña, espátula, garceta, garza, ibis, nidificación.

\section{INTRODUCTION}

Habitat loss is a major threat for the conservation of many bird species, particularly in wetlands, approximately $50 \%$ of whose surface has been lost during the $20^{\text {th }}$ century through drainage for agriculture and urban development, or transformation into artificial wetlands managed for food or salt production (Mitsch and Gosselink, 2000). However, some waterbirds may benefit from such transformed wetlands as ricefields (Fasola et al., 1996; Toral and Figuerola, 2010), salt pans (Feunteun and Marion, 1994; Chokri and Selmi, 2011) or aquaculture ponds (Fleury and Sherry, 1995; Ashkenazi and Yom-Tov, 1996; Young, 1998; Lekuona, 2002).

In the Mediterranean region artificial wetlands represent approximately one quarter of the total surface of wetlands (Perennou et al., 2012). Long-term studies in this region have shown the importance of man-made wetlands on the breeding populations of wading birds (Tourenq et al., 2000, Fasola et al., 2010) as well as on their wintering populations (Rendón et al., 2008).

In this paper, we analyse the results of 27 years of censuses (1984-2010) of the colonies in Doñana (southern Spain). Our main objectives are: 1) to assess the sizes and long-term trends of breeding populations for nine colonial waterbird species; and 2) to analyse how environmental and anthropogenic factors such as, respectively, precipitation and changes in land-use and management regimes are related to fluctuations in population size over time. Doñana is one of the most important wetlands in Europe and in the Mediterranean region for waterbirds (Martí and del Moral, 2003; Rendón et al., 2008; Garrido et al., 2012). Although some previous studies have focused on breeding population trends of some species of wading birds in Doñana (de le Court and Feria, 2009; Máñez and RendónMartos, 2009; Máñez et al., 2010; Santoro et al., 2010), here we present the first systematic and comparative study of its colo- 
nial wading bird populations and their relation to habitat changes over time. Because of the importance of Doñana even at a continental scale, population changes in this area may have an effect on a broader scale, for example at that of metapopulations around the western Mediterranean region).

\section{MATERIALS AND METHODS}

\section{Study area}

Doñana is located in the Guadalquivir River Basin, southwest Spain (fig. 1), where the climate is Mediterranean with some Atlantic influence (García Novo et al., 2007). The mean annual precipitation during the study was $586 \mathrm{~mm}$, ranging from $170 \mathrm{~mm}$ to $1,028 \mathrm{~mm}$ (fig. 2), $84 \%$ falling in autumn and winter.

The area of marshes at the beginning of $20^{\text {th }}$ century was estimated at 135,000 180,000 ha (Castroviejo, 1993; Casas and Urdiales, 1995; Corominas, 1995; Bayán and Dolz, 1995). Extensive drainage, mainly for agriculture, began in 1921-1926 and since 1931 an increasing area has been transformed into ricefields (fig. 3; González, 1993; Federación de Arroceros de Sevilla,

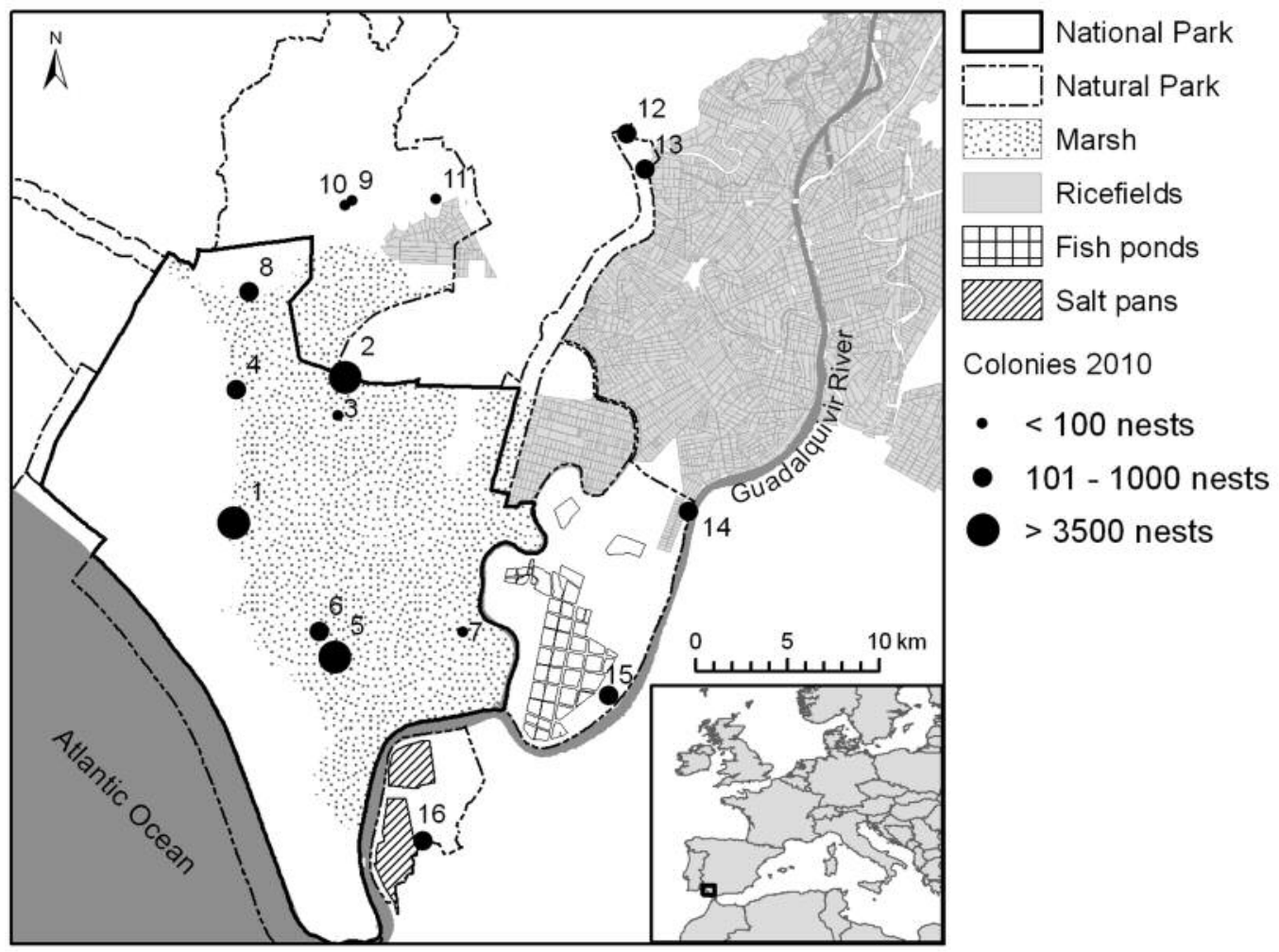

FIG. 1.-Location of wading bird colonies in the Doñana Natural Space in 2010. Names and colony sizes are given in table 1 .

[Situación de las colonias de aves zancudas en el Espacio Natural de Doñana en 2010. En la tabla 1 se proporcionan el nombre y el tamaño de las colonias.] 


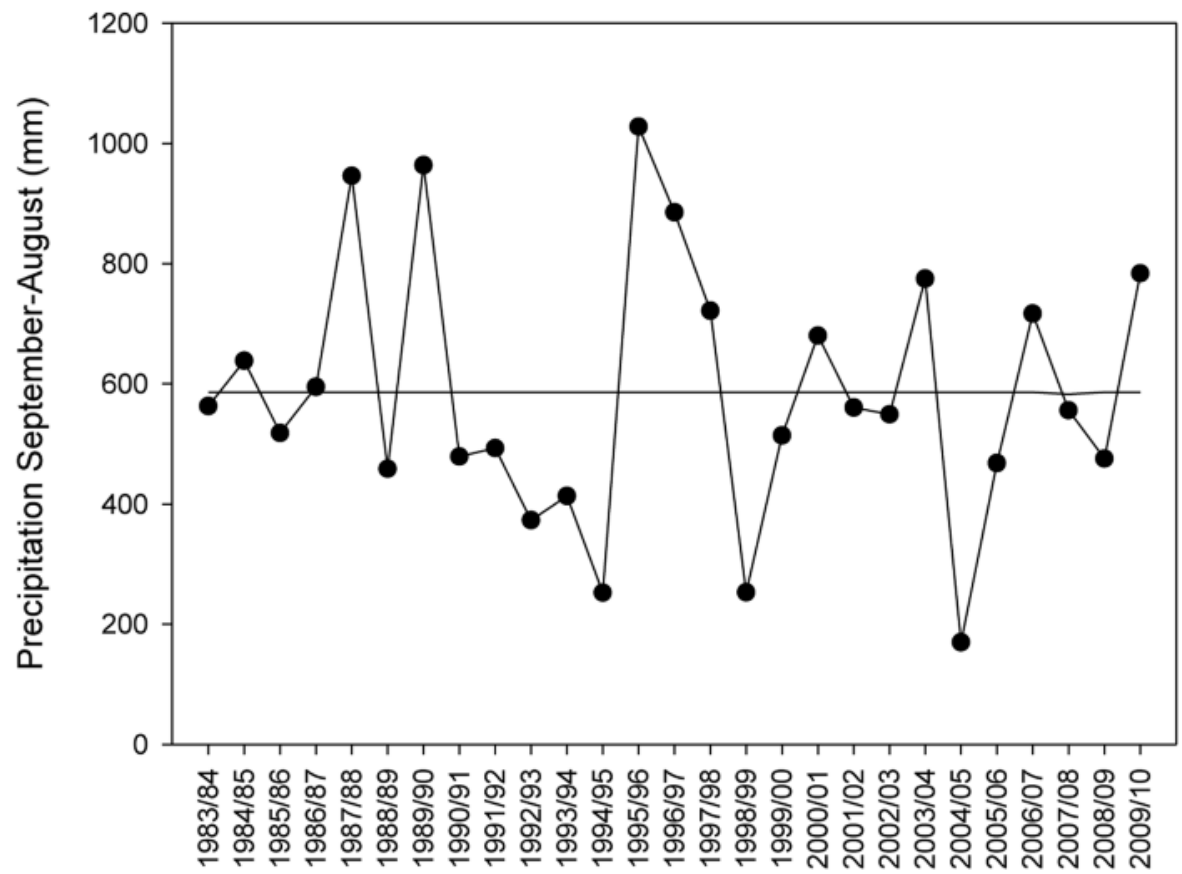

FIG. 2.-Accumulated precipitation (September-August) at the Palacio de Doñana from 1984 to 2010. The horizontal line represents the mean values for this period.

[Precipitación acumulada (septiembre-agosto) en el Palacio de Doñana durante 1984-2010. La línea horizontal representa el valor medio para ese periodo.]

pers. comm.). Transformation for salt extraction began in the $14^{\text {th }}$ century (Alonso et al., 2004), although the current area of salt pans is $<3,000$ ha.

Almost all natural marshes on the east bank of the Guadalquivir river have been drained. On the west bank, 27,000 ha of natural marshes were protected in Doñana National Park, which was designated in 1969 and extended in 1978 and again in 2004. The total extent of the National Park, including terrestrial habitats, is now 54,251 ha. In 1989, an additional area of 54,250 ha surrounding the National Park was designated as Doñana Natural Park, with weaker protection, to act as a discontinuous buffer zone. In 1992-1993, 3,125 ha in the Veta la Palma estate, within the Natural Park, were transformed into fish ponds. The main cultivated species include flathead mullet Mugil cephalus, gilthead seabream Sparus auratus and European seabass Dicentrarchus labrax as well as Atlantic ditch shrimp Palaemonetes varians (see Kloskowski et al., 2009 for details). Between 1996 and 2005, two important areas of previously transformed marsh were restored, largely by eliminating the drainage system: the Marisma Gallega in the Natural Park $(1,800 \mathrm{ha})$ and the Caracoles Estate $(2,890$ ha), which was then incorporated into the National Park (García-Novo and Marín, 2006; Frisch et al., 2012). In 1999, the Natural and National Parks were unified as the Doñana Natural Space to enable management by the same administration. From hereon, 'Doñana' refers to this combined protected area. 


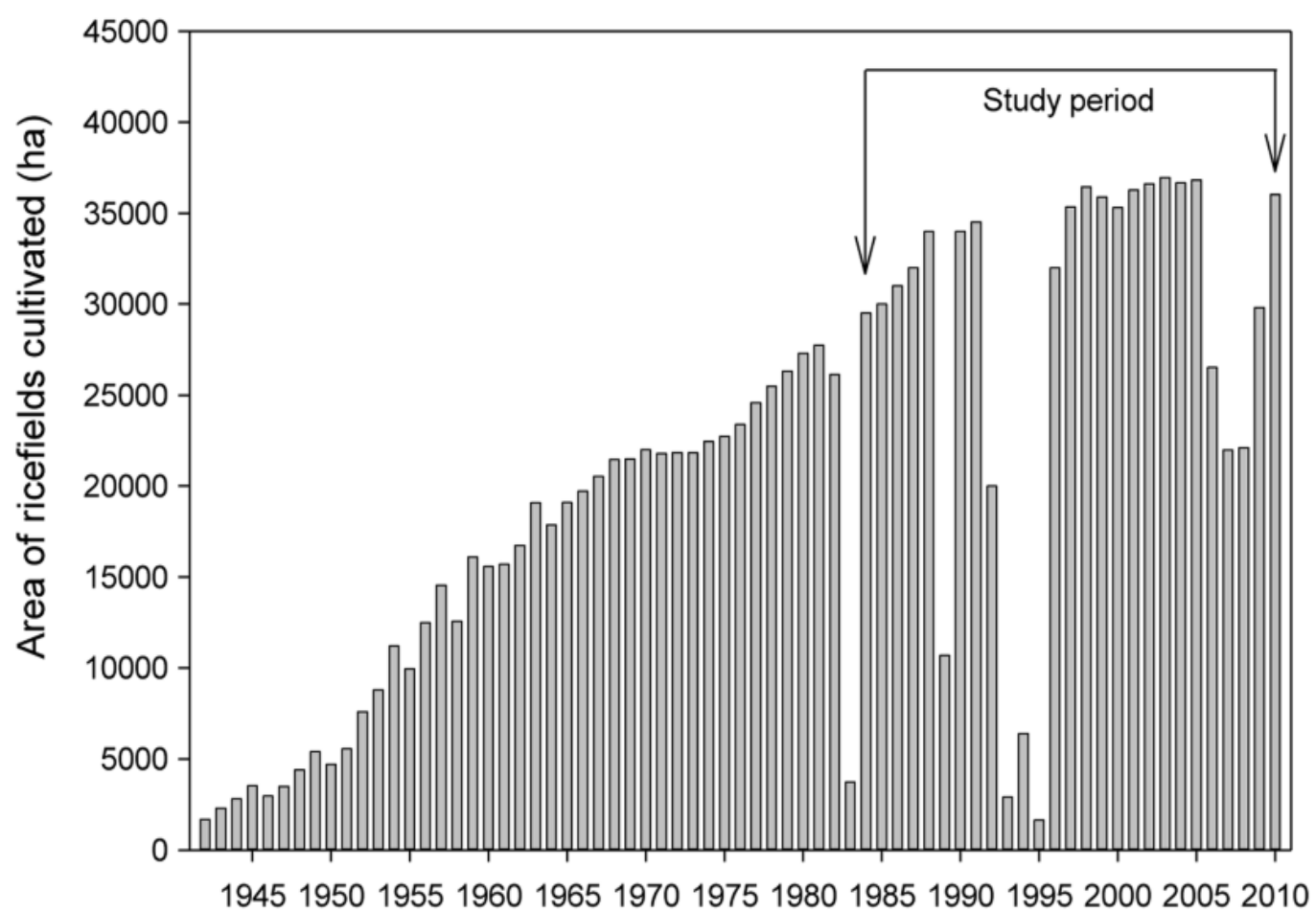

FIG. 3.- Area of ricefields cultivated in the Guadalquivir marshes from 1942 to 2010. [Superficie cultivada de arrozal en las marismas del Guadalquivir durante 1942-2010.]

\section{Survey methods}

This study focuses on nine species of colonial wading birds: the Eurasian spoonbill Platalea leucorodia, glossy ibis Plegadis falcinellus, white stork Ciconia ciconia and six heron species: the black-crowned night heron Nycticorax nycticorax, squacco heron Ardeola ralloides, cattle egret Bubulcus ibis, little egret Egretta garzetta, grey heron Ardea cinerea and purple heron Ardea purpurea. Storks can nest solitarily or in colonies, and for this study only breeding pairs nesting in colonies were considered because counts of individual nests have not been exhaustive nor made with a consistent effort during the study period. From 1984 to 2010 all breeding colonies in Doñana Natural Space were cen- sused by the Monitoring Team at Doñana Biological Station. Purple herons and storks were only counted in the National Park, and purple herons were only censused since 1994 . Census methods depended on the colony. In colonies located in tall trees, monthly censuses were made at a distance by telescope in order to minimise disturbance and to prevent chicks from falling out of nests. For each species, the count was taken as the maximum number of simultaneous active nests. The tree canopy made it impossible to observe all nests, so the numbers obtained probably underestimate the number of breeding pairs. For colonies located on marsh vegetation or small trees, observers entered the colony on foot or on horseback to count nests. The census method for each 
colony was the same throughout the study period, facilitating the estimation of population trends.

\section{Factors affecting breeding population size}

We used local rainfall, which is a reliable indicator of the area of inundated marshes (Almaraz et al., 2012), and the surface area of ricefields as local environmental factors that potentially may affect the number of breeding pairs. Rainfall in the Sahel, the main wintering area of migrant species (Zwarts et $a l ., 2009)$, was also included as a predictor variable because it may affect the winter survival of these species (see Mihoub et al., 2010). The annual amount of local rainfall during September-March inclusive was obtained from the Palacio de Doñana meteorological station (http://www.rbd.ebd.csic.es/ Seguimiento/mediofisico/parametrosmeteo rologicos/lluvia.htm), and the ricefield surface area was provided by the Federación de Arroceros de Sevilla (pers. comm.). For the Sahel, an annual precipitation index for the preceding June-December was used (http://jisao.washington.edu/data/sahel/).

We collected information about all anthropogenic activities that could affect the wading birds after the creation of the $\mathrm{Na}$ tional Park. To evaluate the impact of the construction of fish ponds in Veta la Palma (in 1992-93) and the restoration of Marisma Gallega (mainly in 1996-97) on wading bird feeding habitats, we compared the proportion of birds counted in these areas relative to total aerial counts for Doñana and ricefields along the west bank of the Guadalquivir river before and after these changes (i.e. 1980-1991 versus 1994-2010 for Veta la Palma, and 1985-1995 versus 1998-2010 for Marisma Gallega). We used monthly aerial censuses carried out by the Monitoring Team of Doñana Biological Station (http://www.rbd.ebd.csic.es/Seguimiento/ mediobiologico/censosaereos/censosaereos. $\mathrm{htm}$ ) for three species: A. cinerea, C. ciconia and P. leucorodia. For each season we calculated the average percentage of birds from the available census (from 1 to 3 surveys) that were counted in Veta la Palma and in Marisma Gallega.

\section{Statistical methods}

The TRIM (Trends and Indices for Monitoring Data) program (Pannekoek and van Strien, 2001) was used to test for long-term trends in Doñana breeding populations. This software analyses time series of counts, using Poisson regression. We used the time effects model with imputed indices, considering serial correlation and overdispersion.

We applied Generalised Additive Models (GAMs) to assess the importance of year, rainfall in Doñana, rainfall in the Sahel and ricefield surface area on breeding population size. Separate models were fitted for each species using negative binomial distributed error terms and a log link (Wood, 2006). Each independent variable was entered as a linear term or as a smoother taking up to 3 degrees of freedom. GAMs were fit using the gam function in the R-package "mgcv". Smooth terms were selected using automatic smoothing selection based on Un-Biased Risk Estimator as implemented in the package, using an upper limit of 3 for the number of knots. We followed a forward model selection procedure based on Akaike's Information Criteria (AIC; Burnham and Anderson, 2002). When several models differed in AIC by less than 2 we selected the model including only statistically significant parameters $(P<0.05)$.

Mann-Whitney U tests were used to compare the percentages of individuals using Veta la Palma and Marisma Gallega, before and after the habitat changes. Non-parametric Spearman's rank correlation tests 
were used on time series data to test if the amount of rainfall and ricefield surface area had significant trends. These last two statistical analyses were performed using the STATISTICA 6 package.

\section{RESULTS}

Censuses made systematically every year from 1984 onwards showed a strong increase in the number of both colonies and breeding pairs (fig. 4), reaching a maximum of 17,297 pairs in 2010 (table 1). The number of species per colony varied between one and seven. Eleven colonies were situated in trees or bushes (cork oaks Quercus suber, stone pines Pinus pinea, Eucalyptus sp., wild olives Olea europaea, tamarisk Tamarix sp., poplars Populus alba and willows Salix sp.) and five in marsh vegetation (Phragmites australis, Typha domingensis and Schoenoplectus litoralis). Storks, grey herons and spoonbills only nested in trees, and purple herons only in marsh vegetation. The other species used both substrates.

During this period, all population trends recorded were positive and statistically sig-

FIGURE 4
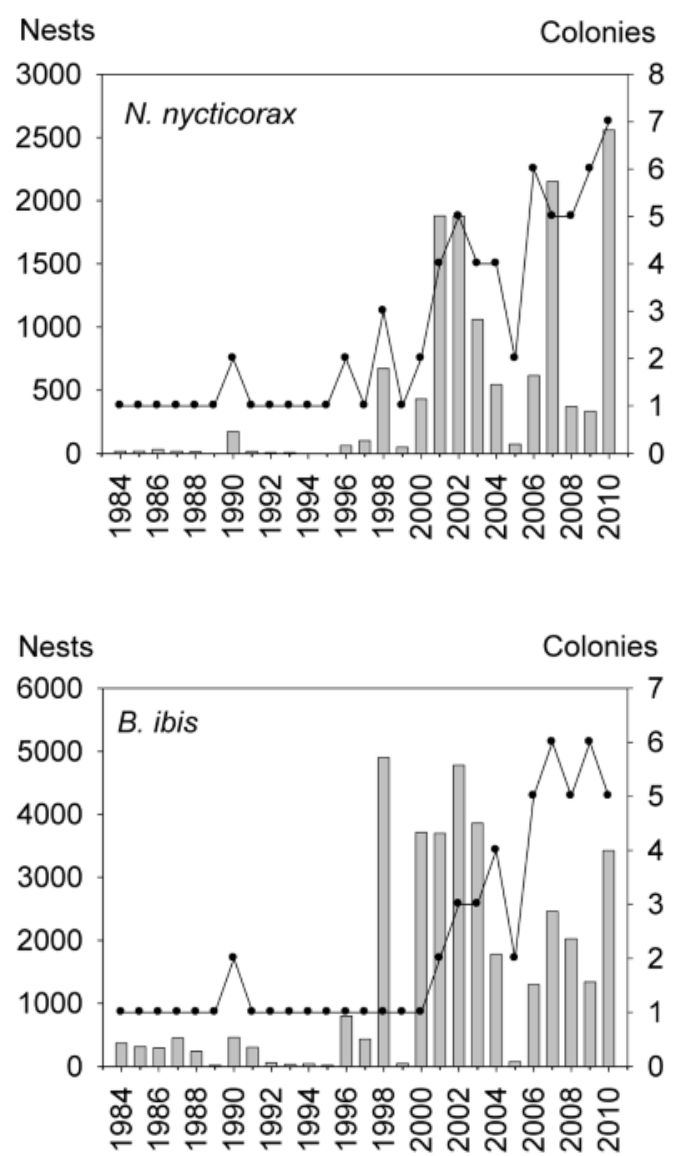
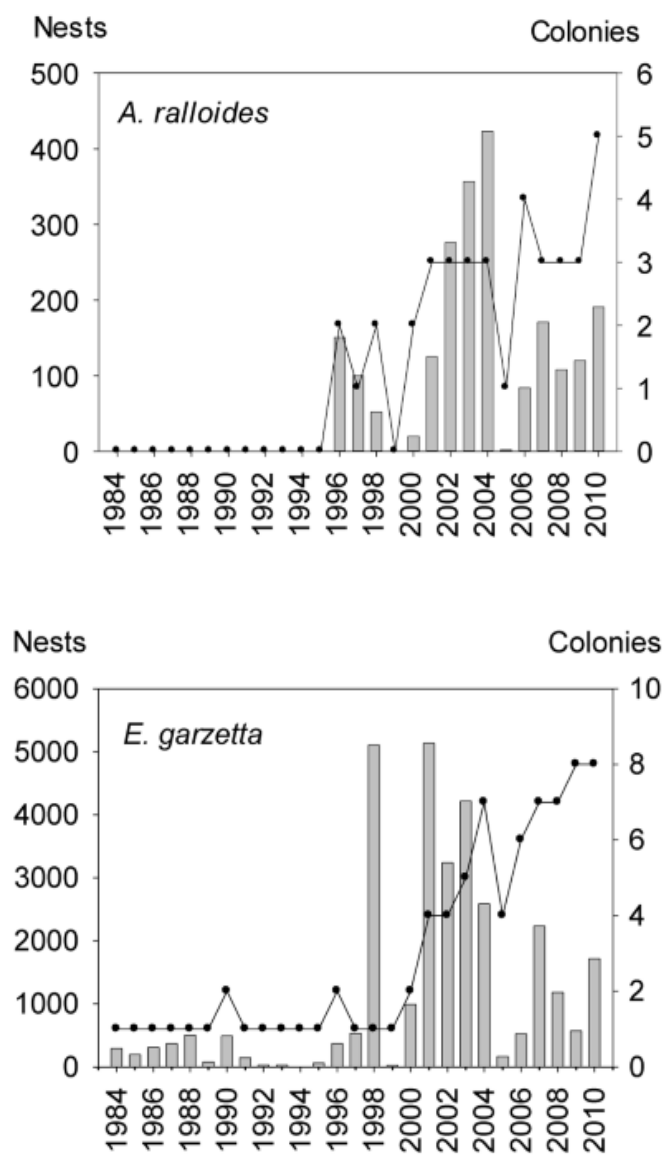

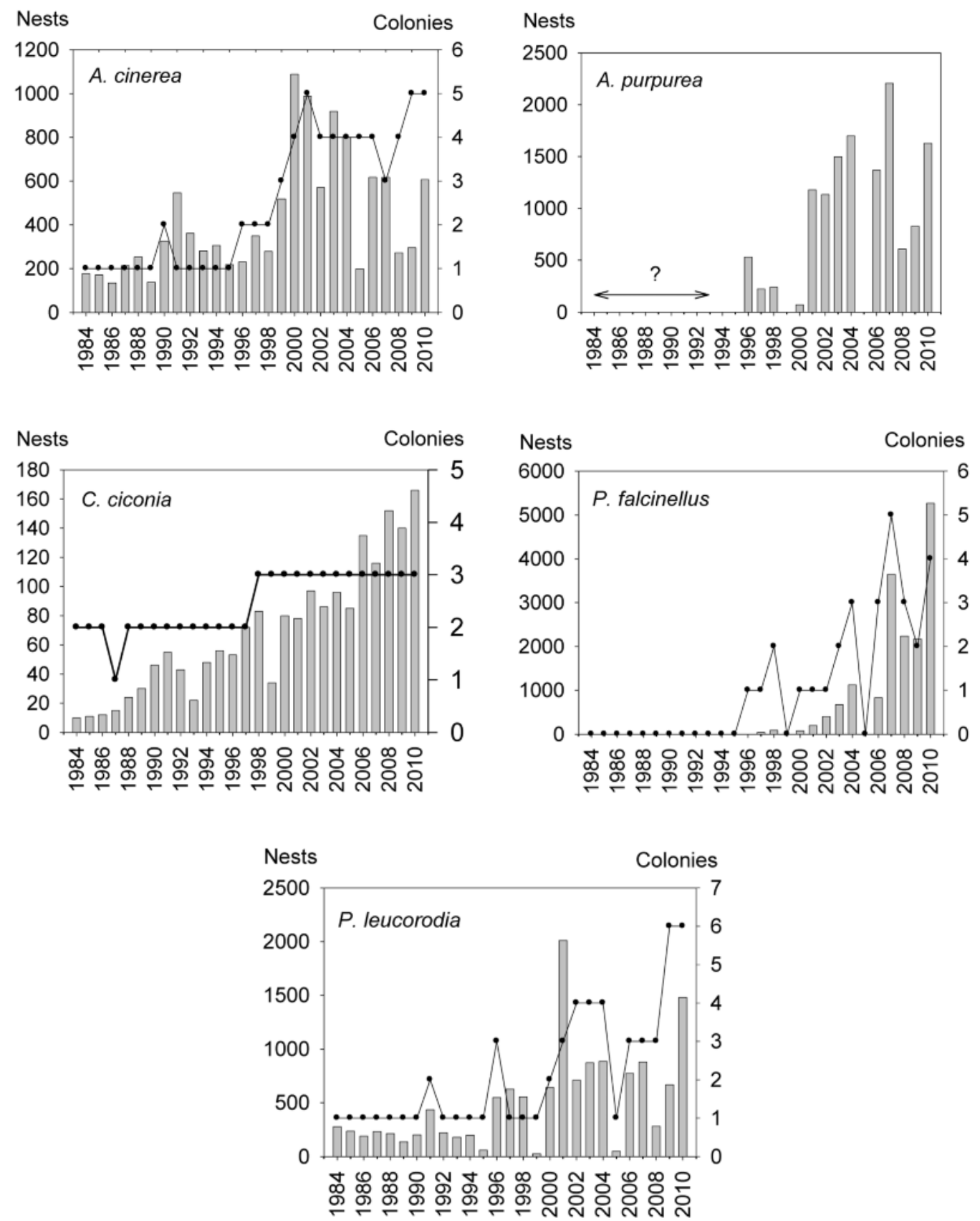

FIG. 4.-Annual variation in the number of nests (bars) and colonies (lines) in Doñana National and Natural Parks combined. For Ardea purpurea and Ciconia ciconia, numbers correspond only to the National Park.

[Número de nidos (barras) y colonias (líneas) en los parques nacional y natural combinados. En el caso de Ardea purpurea y Ciconia ciconia los números corresponden sólo al parque nacional.] 
nificant (table 2). Nevertheless, if this period is split into two, for 1984-1996 only the grey heron and stork showed a significant positive trend, with a significant negative trend for the little egret, cattle egret and spoonbill. On the other hand, for 1996-2010, all species had significant positive trends, with annual increases from $4 \%$ to $51 \%$ (table 2). This contrasts with European trends, where the squacco and purple herons and the glossy ibis showed a moderate decline, while populations of night herons and spoonbills were considered stable during 1990-2000 (BirdLife International, 2004).

Rainfall in Doñana was positively related to breeding population size of all species, apart from the white stork. The relationship with rainfall was curvilinear with a plateau slightly above $500 \mathrm{~mm}$. Ricefield area was related to population size of purple, grey

TABLE 1

Nesting substrates and colony sizes in the Doñana Natural Space in 2010.

[Sustratos vegetales de nidificación y tamaño de las colonias en el Espacio Natural de Doñana en 2010.]

\begin{tabular}{|c|c|c|c|c|}
\hline $\mathbf{N}^{\mathbf{o}}$ & Colony name & Substrate & $\mathbf{N}^{0}$ of species & Size \\
\hline 1 & Pajarera & $\begin{array}{l}\text { Quercus suber } \\
\text { Populus alba } \\
\text { Salix sp. }\end{array}$ & 7 & 5818 \\
\hline 2 & Cerrado Garrido & $\begin{array}{l}\text { Typha dominguensis } \\
\text { Tamarix canariensis }\end{array}$ & 6 & 4628 \\
\hline 3 & Caño Guadiamar & Schoenoplectus litoralis & 1 & 70 \\
\hline 4 & Plaíto (Caño de La Madre) & Schoenoplectus litoralis & 1 & 130 \\
\hline 5 & Juncabalejo & Phragmites australis & 5 & 3984 \\
\hline 6 & Chujarro & Phragmites australis & 3 & 782 \\
\hline 7 & Huerto de los Zorros & Eucalyptus sp. & 3 & 98 \\
\hline 8 & Matasgordas & $\begin{array}{l}\text { Quercus suber } \\
\text { Fraxinus angustifolia } \\
\text { Olea europaea var. sylvestris }\end{array}$ & 1 & 121 \\
\hline 9 & Coto del Rey 1 & Eucalyptus sp. & 1 & 31 \\
\hline 10 & Coto del Rey 2 & Tetraclinis articulata & 1 & 16 \\
\hline 11 & Hato Blanco Viejo & Eucalyptus sp. & 3 & 41 \\
\hline 12 & Casa Neves & Eucalyptus sp. & 5 & 426 \\
\hline 13 & Vado Don Simón & Tamarix sp. & 3 & 530 \\
\hline 14 & Tarfia & Eucalyptus sp. & 3 & 198 \\
\hline 15 & Tierra Baja & Eucalyptus sp. & 5 & 212 \\
\hline 16 & Laguna del Tarelo & Tamarix sp & 5 & 212 \\
\hline
\end{tabular}


TABLE 2

Numerical trends of breeding populations of wading birds in Doñana and Europe.

[Tendencias numéricas de las poblaciones reproductoras de aves zancudas en Doñana y Europa.]

\begin{tabular}{|c|c|c|c|c|c|c|c|}
\hline & \multicolumn{6}{|c|}{$\begin{array}{c}\text { Trend in Doñana } \\
\text { TRIM }\end{array}$} & \multirow{2}{*}{$\begin{array}{c}\text { Trend in Europe } \\
\text { BirdLife International } \\
(2004)\end{array}$} \\
\hline & \multicolumn{2}{|c|}{$1984-2010$} & \multicolumn{2}{|c|}{ 1984-1996 } & \multicolumn{2}{|c|}{$1996-2010$} & \\
\hline Species & Slope & & Slope & & Slope & & \\
\hline N. nycticorax & $1.2376^{* *}$ & $\begin{array}{l}\text { Strong } \\
\text { increase }\end{array}$ & 0.9155 & Uncertain & $1.1477^{* *}$ & $\begin{array}{l}\text { Strong } \\
\text { increase }\end{array}$ & Stable \\
\hline A. ralloides ${ }^{\mathrm{a}}$ & & & & & $1.0872^{*}$ & $\begin{array}{l}\text { Strong } \\
\text { increase }\end{array}$ & Moderate decline \\
\hline B. ibis & $1.1251^{* *}$ & $\begin{array}{l}\text { Strong } \\
\text { increase }\end{array}$ & $0.8714^{* *}$ & $\begin{array}{l}\text { Steep } \\
\text { decline }\end{array}$ & $1.0593^{* *}$ & $\begin{array}{l}\text { Strong } \\
\text { increase }\end{array}$ & Large increase \\
\hline E. garzetta & $1.1084^{* *}$ & $\begin{array}{l}\text { Strong } \\
\text { increase }\end{array}$ & $0.8318^{* *}$ & $\begin{array}{l}\text { Steep } \\
\text { decline }\end{array}$ & $1.0470^{* *}$ & $\begin{array}{l}\text { Moderate } \\
\text { increase }\end{array}$ & Small increase \\
\hline A. cinerea & $1.0474^{* *}$ & $\begin{array}{l}\text { Moderate } \\
\text { increase }\end{array}$ & $1.0506^{* *}$ & $\begin{array}{l}\text { Moderate } \\
\text { increase }\end{array}$ & $1.008^{*}$ & $\begin{array}{l}\text { Moderate } \\
\text { increase }\end{array}$ & Moderate increase \\
\hline A. purpurea ${ }^{\mathrm{b}}$ & & & & & $1.1798^{* *}$ & $\begin{array}{l}\text { Strong } \\
\text { increase }\end{array}$ & Moderate decline \\
\hline C. ciconia & $1.1026^{* *}$ & $\begin{array}{l}\text { Strong } \\
\text { increase }\end{array}$ & $1.574^{* *}$ & $\begin{array}{l}\text { Strong } \\
\text { increase }\end{array}$ & $1.0833^{* *}$ & $\begin{array}{l}\text { Strong } \\
\text { increase }\end{array}$ & Moderate increase \\
\hline P. falcinellus ${ }^{\mathrm{a}}$ & & & & & $1.5196^{*}$ & $\begin{array}{l}\text { Strong } \\
\text { increase }\end{array}$ & Moderate decline \\
\hline P. leucorodia & $1.0546^{* *}$ & $\begin{array}{l}\text { Strong } \\
\text { increase }\end{array}$ & $0.9881^{*}$ & $\begin{array}{l}\text { Moderate } \\
\text { decline }\end{array}$ & $1.0419^{* *}$ & $\begin{array}{l}\text { Moderate } \\
\text { increase }\end{array}$ & Stable \\
\hline
\end{tabular}

*, $P<0.05 ; \quad * *, P<0.01$

a These species returned to nest in Doñana in 1996

b No data are available before 1994

Trend classification (TRIM program):

Strong increase: significantly greater than $5 \%$ per year.

Moderate increase: significant but less than $5 \%$ per year.

Uncertain: no significant increase or decline; uncertain whether trends are less than $5 \%$ per year.

Moderate decline: significant, but less than $5 \%$ per year.

Steep decline: significantly greater than $5 \%$ per year. 
and night herons, and little and cattle egrets. Breeding population size was positively associated with the year, but no significant trend was found with respect to rainfall in the Sahel for the nine species (table 3, fig. 5).

The springs of 1995, 1999 and 2005 were preceded by very dry winters, and neither the purple heron nor the glossy ibis bred in any of these years. Other species bred in very small numbers, even though the ricefield area was $1,641,35,887$ and 36,827 ha, respectively, in those years.

Despite their importance in explaining variation in breeding numbers, neither the precipitation in autumn-winter $\left(r_{s}=-0.01\right.$, $N=27, P=0.94)$ nor the surface area of ricefields $\left(r_{s}=0.32, N=27, P=0.11\right)$ in our study area have experienced a significant increase during the study period. Hence, these two variables alone cannot explain the positive population trends of all species in Doñana.

The creation of fish ponds and restoration of the Marisma Gallega may have had an important influence on population trends, contributing to the positive trends for all species since 1996 (table 2). The proportion of the Doñana spoonbill population using Veta la

TABLE 3

Results of GAMs analysing changes in numbers of breeding pairs in Doñana during 1984-2010 (19942010 for A. purpurea). Significance levels given for linear (1) or smooth terms (s) for year, rainfall in Doñana and ricefield surface are, together with the percentage of deviance explained for each species. Significance of the linear trends is tested from z scores and of smoothers from chi-squares. Rainfall in Sahel was not significantly related to breeding population size.

[Resultados de los modelos generales aditivos (GAMs) utilizados para analizar los cambios en el número de parejas reproductoras en Doñana durante el periodo 1984-2010. Para A. purpurea el periodo de estudio fue 1994-2010. Se da el nivel de significación de los términos lineal (l) o "smooth" (s) para el año, la precipitación en Doñana y la superficie de arrozal, junto con el porcentaje de devianza explicada para cada especie. La significación de las tendencias lineales se testó con el valor de z. y la de los "smoothers" con chi-cuadrado. La precipitación en el Sahel no estuvo relacionada con el tamaño de la población reproductora.]

\begin{tabular}{|c|c|c|c|c|c|}
\hline Species & & Year & Rain Doñana & Rice fields & Deviance \% \\
\hline N. nycticorax & $\mathrm{s}$ & $<0.0001$ & 0.0001 & 0.0001 & 80.9 \\
\hline A. ralloides & $\mathrm{s}$ & $<0.0001$ & $\mathrm{~s}<0.0001$ & & 93.3 \\
\hline B.ibis & $\mathrm{s}$ & $<0.0001$ & $\mathrm{~s}<0.0001$ & $\mathrm{~s}<0.0001$ & 78.9 \\
\hline E. garzetta & $\mathrm{s}$ & $<0.0001$ & $\mathrm{~s}<0.0001$ & 0.0003 & 76.0 \\
\hline A. cinerea & $\mathrm{s}$ & $<0.0001$ & 0.03 & 0.03 & 67.4 \\
\hline A.purpurea & $\mathrm{s}$ & 0.004 & $\mathrm{~s}<0.0001$ & 0.006 & 92.1 \\
\hline C. ciconia & $\mathrm{s}$ & $<0.0001$ & & & 86.7 \\
\hline P.falcinellus & $\mathrm{s}$ & $<0.0001$ & $\mathrm{~s}<0.0001$ & & 96.9 \\
\hline P. leucorodia & $\mathrm{s}$ & $<0.0001$ & $\mathrm{~s}<0.0001$ & & 78.4 \\
\hline
\end{tabular}


TABLE 4

Percentage of individuals located in Veta la Palma before (1980-1991) and after (1994-2010) fish pond construction (1992-1993) based on monthly aerial counts from Doñana and ricefields along the west bank of the Guadalquivir river.

[Porcentaje de individuos localizados en Veta la Palma antes (1980-1991) y después (1994-2010) de la construcción de los estanques de piscicultura (1992-1993), basado en censos aéreos mensuales de Doñana y de los arrozales de la margen oeste del río Guadalquivir.]

\begin{tabular}{|c|c|c|c|c|c|c|c|c|c|c|c|}
\hline \multirow[b]{2}{*}{ Species } & \multirow[b]{2}{*}{ Season } & \multicolumn{4}{|c|}{$1980-1991$} & \multicolumn{4}{|c|}{$1994-2010$} & \multirow[b]{2}{*}{$U$} & \multirow[b]{2}{*}{$P$-value } \\
\hline & & 2 & & & & 2 & & & $\frac{3}{3}$ & & \\
\hline \multirow{4}{*}{ A. cinerea } & January-March & 12 & 14.1 & 1.7 & 37.6 & 17 & 14.5 & 0.7 & 27.9 & 100.0 & 0.929 \\
\hline & April-June & 9 & 1.1 & 0.0 & 12.4 & 16 & 2.6 & 0.8 & 17.9 & 51.0 & 0.234 \\
\hline & July-September & 11 & 7.9 & 1.5 & 29.3 & 16 & 16.5 & 3.4 & 33.5 & 47.0 & $0.043^{*}$ \\
\hline & October-December & 12 & 15.6 & 0.0 & 46.0 & 17 & 35.6 & 0.0 & 58.5 & 47.0 & $0.015^{*}$ \\
\hline \multirow{4}{*}{ C. ciconia } & January-March & 12 & 0.1 & 0.0 & 56.9 & 17 & 1.4 & 0.0 & 15.0 & 86.0 & 0.472 \\
\hline & April-June & 8 & 0.0 & 0.0 & 3.5 & 16 & 1.6 & 0.0 & 26.5 & 26.0 & $0.017^{*}$ \\
\hline & July-September & 11 & 3.0 & 0.0 & 47.5 & 16 & 7.1 & 0.0 & 34.6 & 78.0 & 0.620 \\
\hline & October-December & 12 & 0.0 & 0.0 & 98.8 & 17 & 1.0 & 0.0 & 11.5 & 88.5 & 0.535 \\
\hline \multirow{4}{*}{ P. leucorodia } & January-March & 12 & 2.1 & 0.0 & 55.8 & 17 & 25.3 & 0.0 & 66.4 & 54.0 & $0.032^{*}$ \\
\hline & April-June & 9 & 0.0 & 0.0 & 1.2 & 16 & 11.9 & 0.0 & 53.8 & 10.0 & $0.000^{* * *}$ \\
\hline & July-September & 11 & 8.7 & 0.0 & 46.0 & 16 & 39.0 & 2.1 & 65.0 & 40.0 & $0.018^{*}$ \\
\hline & October-December & 12 & 12.8 & 0.0 & 76.2 & 17 & 47.7 & 0.0 & 80.2 & 65.0 & 0.100 \\
\hline
\end{tabular}

Palma has increased strikingly after fish pond construction (table 4 ), e.g. from 0 to $12 \%$ in spring. Significant increases have also occurred for grey herons in the postbreeding period and for storks in spring. Similar increases in the proportion of birds from these three species using the Marisma Gallega were also observed after restoration (table 5), with particularly strong increases for spoonbills (e.g. a change from 0 to $15 \%$ in autumn).

\section{DisCUSSION}

Although all nine study species have increased significantly in Doñana since 1984, and especially since 1995, only four of these species are considered to be increasing at an European level. This suggests that the positive trends are largely connected with local factors operating in Doñana, and do not reflect processes acting on a continental scale. 


\section{TABLE 5}

Percentage of individuals located in Marisma Gallega before (1980-1995) and after (1998-2010) marsh restoration based on monthly aerial counts from Doñana and ricefields along the west bank of the Guadalquivir river.

[Porcentaje de individuos localizados en la Marisma Gallega antes (1980-1995) y después (1998-2010) de su restauración, basado en censos aéreos mensuales de Doñana y de los arrozales de la margen oeste del río Guadalquivir.]

\begin{tabular}{|c|c|c|c|c|c|c|c|c|c|c|c|}
\hline \multirow[b]{2}{*}{ Species } & \multirow[b]{2}{*}{ Season } & \multicolumn{4}{|c|}{ 1980-1995 } & \multicolumn{4}{|c|}{ 1998-2010 } & \multirow[b]{2}{*}{$U$} & \multirow[b]{2}{*}{$P$-level } \\
\hline & & 2 & & & 3 & 2 & & & 3 & & \\
\hline \multirow{4}{*}{ A. cinerea } & January-March & 16 & 2.7 & 0.0 & 19.8 & 13 & 2.1 & 0.3 & 32.6 & 87.0 & 0.455 \\
\hline & April-June & 12 & 1.8 & 0.0 & 43.9 & 13 & 1.0 & 0.4 & 17.3 & 77.0 & 0.957 \\
\hline & July-September & 14 & 6.2 & 0.9 & 38.9 & 13 & 6.6 & 0.0 & 27.0 & 87.0 & 0.846 \\
\hline & October-December & 16 & 0.8 & 0.0 & 7.6 & 13 & 8.1 & 0.0 & 45.4 & 57.0 & $0.038^{*}$ \\
\hline \multirow{4}{*}{ C. ciconia } & January-March & 16 & 0.0 & 0.0 & 9.7 & 13 & 3.0 & 0.0 & 16.4 & 61.0 & $0.048^{*}$ \\
\hline & April-June & 12 & 0.0 & 0.0 & 14.3 & 13 & 2.2 & 0.0 & 5.1 & 40.0 & $0.034^{*}$ \\
\hline & July-September & 14 & 1.2 & 0.0 & 30.4 & 13 & 5.3 & 0.0 & 15.8 & 73.0 & 0.382 \\
\hline & October-December & 16 & 0.0 & 0.0 & 16.1 & 13 & 3.9 & 0.0 & 10.1 & 54.0 & $0.018^{*}$ \\
\hline \multirow{4}{*}{ P. leucorodia } & January-March & 14 & 0.0 & 0.0 & 0.1 & 13 & 1.6 & 0.0 & 19.0 & 8.5 & $0.000^{* * *}$ \\
\hline & April-June & 13 & 0.0 & 0.0 & 47.9 & 13 & 1.4 & 0.0 & 10.9 & 64.0 & 0.288 \\
\hline & July-September & 14 & 2.8 & 0.0 & 73.3 & 13 & 15.0 & 0.0 & 39.1 & 37.0 & $0.008^{* *}$ \\
\hline & October-December & 16 & 0.0 & 0.0 & 0.0 & 13 & 15.4 & 0.0 & 32.2 & 24.0 & $0.000^{* * *}$ \\
\hline
\end{tabular}

\section{Environmental factors}

The amount of rainfall in the preceding autumn/winter is the main determinant of the number of breeding pairs for all species, except for the white stork. The stork has the lowest trophic dependence on flooded areas and its breeding distribution is not closely related to that of wetlands (Martí and del Moral, 2003). The flooding of the Guadalquivir marshes depends mostly on rainfall (Amat,
1981; Almaraz et al., 2012), and provides feeding habitats for most species and suitable nesting sites for species using marsh vegetation. The curvilinear relationships for local rainfall (fig. 5) suggest that the highest levels of precipitation lead to a reduction in breeding activity, owing to high water depth in the marshes which reduces the area accessible to wading birds. This result is similar to that found for wintering Anatidae, which also reduce their numbers in years of par- 
FIGURE 5

\section{Nycticorax nycticorax}
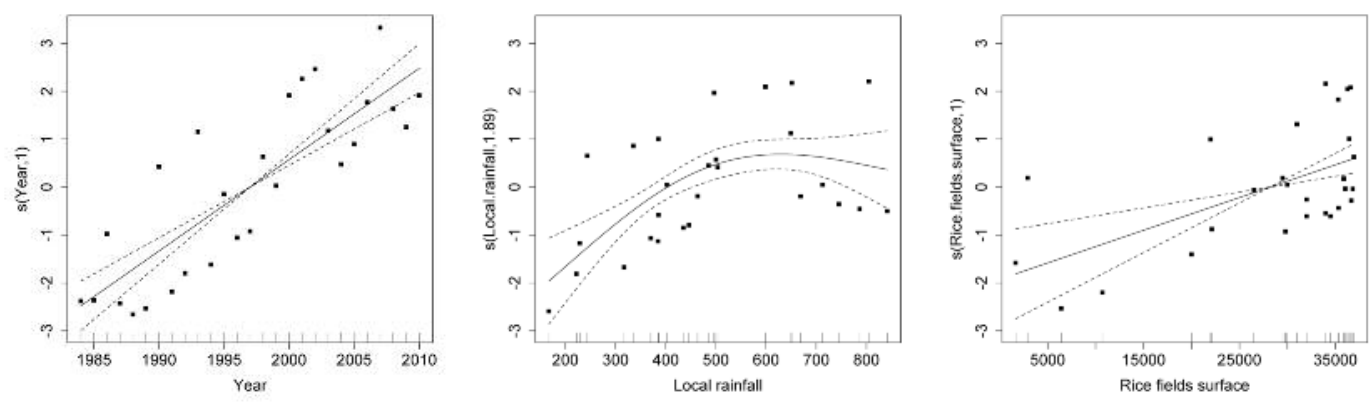

\section{Ardeola ralloides}
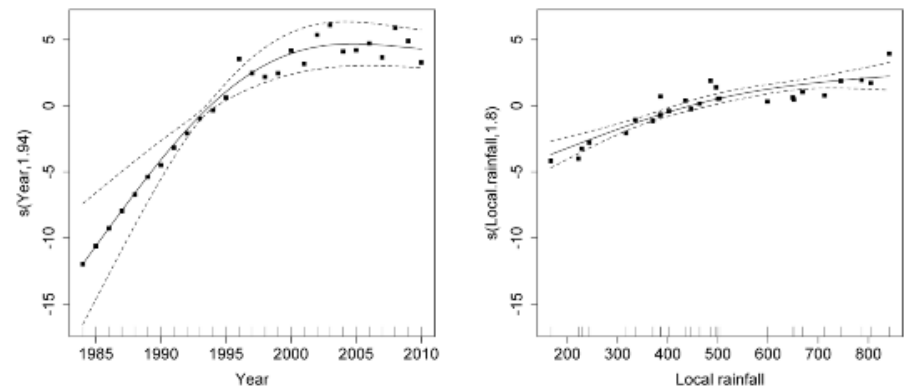

\section{Bubulcus ibis}
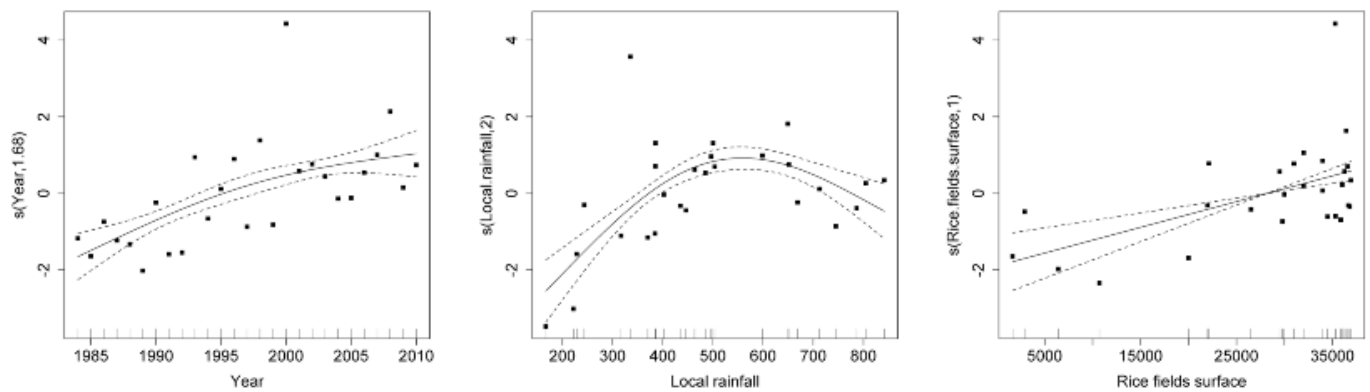

\section{Egretta garzetta}
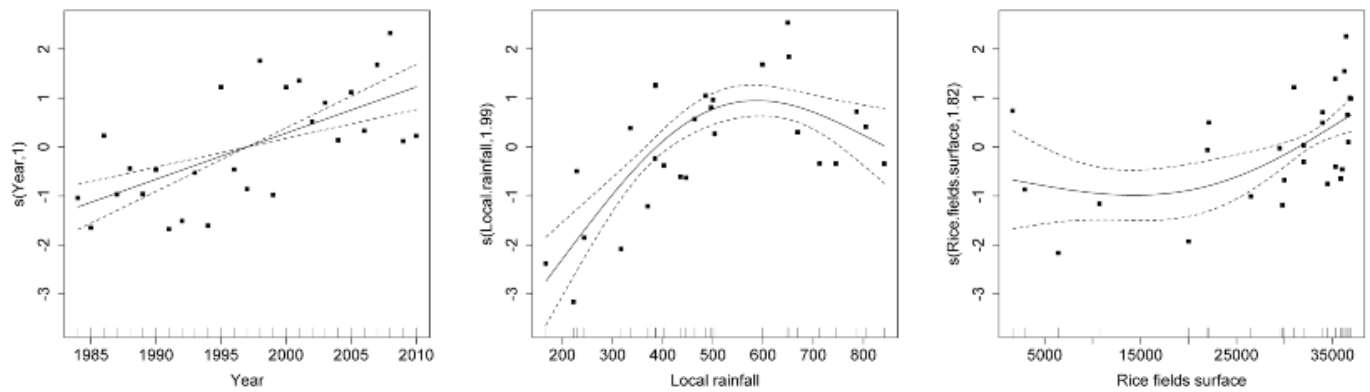

Ardeola 60(2), 2013, 305-326 

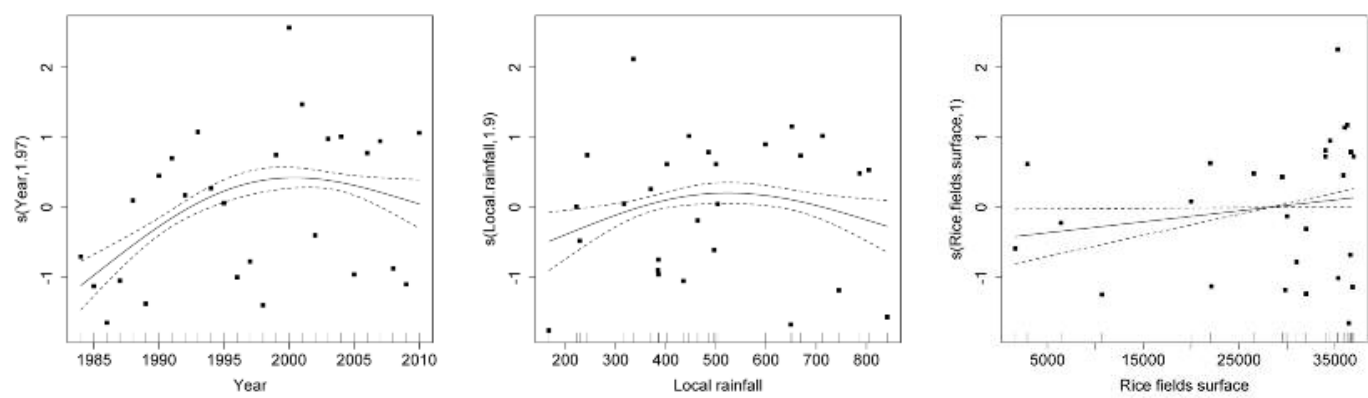

\section{Ardea purpurea}
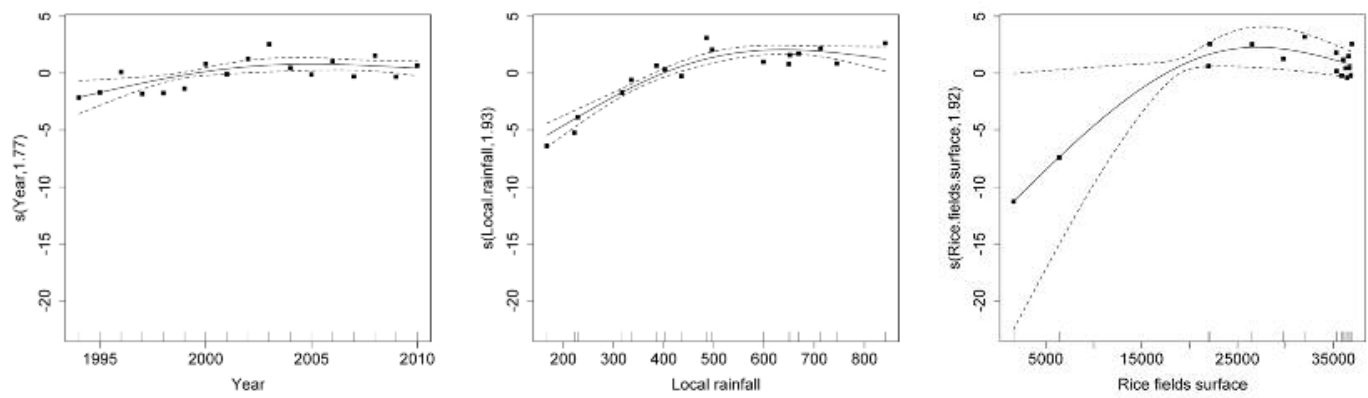

\section{Ciconia ciconia}

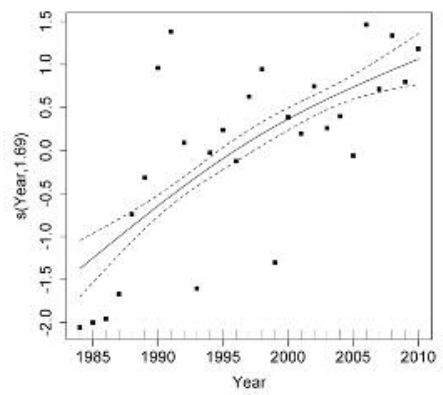

\section{Plegadis falcinellus}
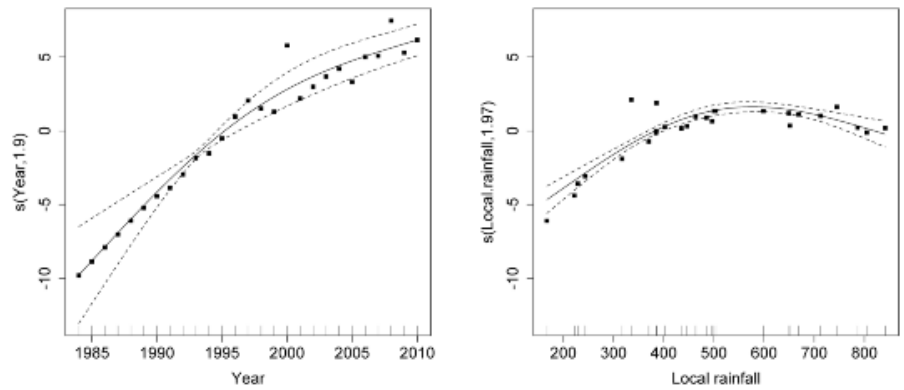
Platalea leucorodia
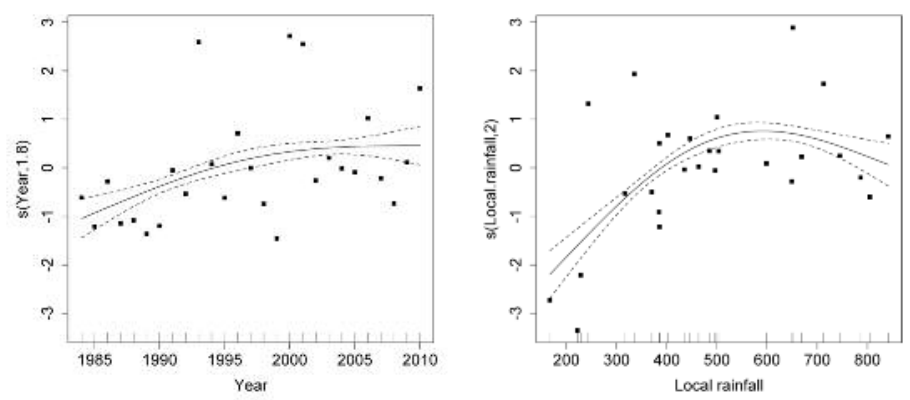

FIG. 5.-Smoothers (and 95\% confidence intervals) for the different independent variables in the final models for each species from table 3. Rainfall is presented in $\mathrm{mm}$ and rice field surface in ha.

["Smoothers" (y 95\% de intervalos de confianza) para las variables independientes en el modelo final para cada especie de la tabla 3. La precipitación se presenta en milímetros y la superficie de arroz en hectáreas.]

ticularly high precipitation (Alamaraz et al., 2012). However, although in the Camargue there is no relationship between the number of heron nests and local rainfall, the number of little egret nests there is negatively related to the amount of rainfall in southern Spain, indicating that unfavourable feeding conditions in the Guadalquivir marshes make birds disperse to alternative breeding sites (Nager et al., 2010). Nevertheless, we did not find a significant correlation between number of little egret nests in the Camargue (Kayser et $a l ., 2003,2008)$ and Doñana during 1984$2006\left(r_{s}=0.35, N=21, P=0.123\right)$.

The conditions on wintering grounds could also be important in the dynamics of wading birds. One of the main predictors of the nesting population of the little egret in the Camargue was the number of birds overwintering the preceding winter (Hafner et al., 1994). Fasola et al. (2000) found significant correlations between population sizes of night and squacco herons in five areas of Europe and rainfall in Africa, and in Italy an increased nesting population for these two species was associated with increased rainfall in the African wintering range (Fasola et al., 2010). In the Netherlands, the population fluctuations of the purple heron during the 1960s and 1970s were strongly related to hydrological conditions in west Africa (Den Held, 1981), while in Germany the nesting number of storks was positively correlated with rainfall on their African wintering grounds (Dallinga and Schoenmakers, 1987). For Doñana breeding populations, we failed to find any relationship with rainfall in the Sahel. Storks are increasingly staying at, or near, to their breeding areas in Spain (Tortosa et al., 1995). Spoonbills usually winter south of the Sahara but exploit intertidal habitats not dependent on rainfall (de le Court and Aguilera, 1997). For purple and squacco herons, populations in Doñana have strongly increased during the study (table 2) and any potential influence of wintering conditions in Africa may have been masked by this trend.

\section{Changes in breeding habitats}

The management of vegetation is an anthropogenic factor that affected the availability of nesting substrate. In the French 
Camargue, a significant decline in the numbers of breeding purple herons was associated with degradation of reed beds by overgrazing or cutting for hunting purposes (Moser, 1984; Kayser et al., 1994; Hafner, 2000; Barbraud et al., 2002). In Doñana, the natural marshes of the National Park are heavily grazed by large herbivores, mainly by a high density of cattle (Soriguer et al., 2001), restricting the growth of reed beds and reducing the area of potential nesting habitats. The construction and fencing of three artificial ponds (1981-1989) that are maintained with groundwater and have developed extensive Typha and Tamarix stands, led to the creation of one of the largest colonies, coinciding with the return of the squacco heron and glossy ibis as breeders in Doñana in 1996 (colony 2, fig.1; Máñez and Garrido, 1996a, 1996b; Santoro et al., 2010). Finally, the fencing of two areas of marshes in 1995 and 1998, to prevent the entry of cattle and other herbivores, led to the development of Phragmites reedbeds now occupied by two new colonies (colonies 5 and 6, fig. 1).

One of the biggest colonies in Doñana is found in relict cork oaks on the edge of the marsh (colony 1, fig. 1). Because the accumulation of guano accelerated the death of cork oaks (García et al., 2011), hundreds of poplars and willows were planted, mainly in 1980s and 1990s, in order to provide an alternative substrate for nesting. In 1985, $12 \%$ of the nests were on riparian vegetation, but this had increased to $82 \%$ by 2010 . The increase of the availability of riparian vegetation has especially benefited the squacco and night herons, and cattle and little egrets.

\section{Changes in protection}

The absence of human disturbance is also important for breeding wading birds. In Italy, grey heron increases were attributed to a decrease in human-induced mortality, and the improved protection of colonies was also important for the long-term population persistence of all species (Fasola et al., 2010). In Doñana, six out of the eight current colonies in the Natural Park were formed after its protection in 1989. Doñana was historically an important hunting and egg collection area. Until the beginning of the $20^{\text {th }}$ century, hunting was concentrated in the area now included in the National Park, although the number of hunters was low (Chapman and Buck, 1893; J. Calderón, pers. com.). In 1982/1983, all hunting was prohibited within the National Park, but hunting of Anatidae and other quarry is still permitted in parts of the Natural Park. In 1983/1984 the hunting period was also shortened, from mid-October to early March, to the current period between the second half of November and late January (J. Calderón, pers. comm.). Thus, disturbance by hunters has declined substantially during February and March, when most species commence breeding.

Another cause of disturbance was generated by the commercial harvest of red swamp crayfish Procambarus clarkii inside the National Park. Besides the mortality of fauna trapped in the nets (e.g. amphibians, snakes, ducklings), the transit of fishermen in the marsh from March to June was a major disturbance for breeding birds (Geiger et al., 2005). In 1979, crayfish harvest began in the National Park and although it was prohibited in 1984 due to its impact on the fauna (Molina, 1984), it continued illegally until the early 1990s.

\section{Changes in feeding habitats}

The surface area of ricefields correlates positively with breeding numbers of grey, purple and night herons, and cattle and little egrets. Rendón et al. (2008) found evidence that the surface area of ricefields influences the number of storks and grey herons win- 
tering in Doñana. Nevertheless ricefields play only a secondary role during the breeding season, because many pairs begin to nest in March and April, before ricefields are flooded in May. However, ricefields may be important for breeding success by providing food during chick rearing and for juveniles after fledging. Ricefields also represent an important habitat for wading birds in other Mediterranean wetlands, with a positive effect on breeding numbers of little egrets (Fasola et al., 2010) and cattle egrets (Tourenq et al., 2000).

Between 1984 and 2010, the most important change in the Doñana marshes was the creation of the Veta la Palma fish farm. Besides the cultivated fish species, the semipermanent fish ponds provide macroinvertebrates and small fishes (Fundulus heteroclitus and Gambusia holbrooki) and may act as complementary habitat to the natural marshes for wading birds, as they do for ducks and shorebirds (Kloskowski et al., 2009), thus improving the carrying capacity of Doñana for spoonbills, grey herons and storks. Given the use of Veta la Palma by little egrets and night herons throughout the year (Toral, 2011), it is likely that these species have also benefited from the creation of fish ponds. As an indirect evidence of the importance of fish ponds for these birds, in Hong Kong the loss of fish ponds caused a decline in the number of little egrets in some colonies (Young, 1998). More directly, Rendón et al. (2008) found that the population trends for waterbirds wintering in Doñana were closely related to the proportion of the population using the fish ponds. Another important change in Doñana that is likely to have increased the number of these species is the restoration of the Marisma Gallega area. Except in the case of the stork, whose numbers have grown continuously, there were important increases in the number of nests in the second half of the 1990s (fig. 4, table 2), after the habitat changes at Veta la Palma and Marisma Gallega.

The introduction of the red swamp crayfish in Doñana has produced important changes in the trophic web of marshes and affected prey availability for wading birds. The crayfish was introduced in 1974 and was widely distributed by 1979 . Its commercial harvest began at the end of the 1970s, and in 1982 more than 2,500 $\mathrm{Tg}$ were captured in Doñana and surrounding ricefields (Geiger et al., 2005). At present, the crayfish has become an important prey for storks, spoonbills and herons in Doñana (Tablado et al., 2010), but apparently not for the purple heron, whose diet has not changed over a 30-year period (Montesinos et al., 2008).

Although Tablado et al. (2010) attributed the increase of wading birds to the invasive red swamp crayfish, its introduction cannot explain the negative trend of the populations of egrets and spoonbills during the first half of our study period (1984-1996) nor the increase of other species such as the greater flamingo Phoencipoterus roseus, blackwinged stilt Himantopus himantopus or pied avocet Recurvirostra avosetta that do not feed on crayfish (Rendón et al., 2008). In addition, the importance of crayfish for some of the species studied here appears limited. For example, the glossy ibis, the species which experienced the greatest increase, does not feed on crayfish during the breeding season (Macías et al., 2004), nor during most of the autumn and winter (Toral et al., 2012), but it consumes crayfish opportunistically during the rice harvest. There have been many other key habitat changes since 1974 (see above), and the available data suggest that the increases in breeding populations of wading birds at Doñana cannot be attributed to a single cause, such as the crayfish, but rather to a set of causes including improved nesting habitat, new feeding habitats and stricter protection measures. 


\section{Future Directions}

Establishing future trends for these wading bird species is difficult. Climate projections in Spain predict an important decrease in rainfall in the area during the second half of this century (AEMET, 2009), that may negatively affect these species. However, greater tidal influence in the Doñana marshes in the future, expected from changing management and sea level rise, may increase feeding areas for some species. The artificial wall preventing the flooding of the marshes with brackish water during high tides is being made permeable as part of a plan to recover former Doñana hydrodinamics. All these factors may have opposing effects on local bird populations and deserve more study in the future.

ACKNOWLEDGEMENTS.- We are grateful to the Doñana Biological Station Monitoring Team, especially Luis García, Héctor Garrido, Rubén Rodríguez, Fernando Ibáñez, José Luis Arroyo, José Luis del Valle, and Alfredo Chico, and also to Juan Manuel Espinar and Francisco Robles from Doñana Natural Space, for conducting aerial counts and the majority of the colony censuses, to David Aragonés from the GIS and Remote Sensing Laboratory (LAST-EBD) who made figure 1, and to Juan Amat who revised the manuscript, providing useful comments. Financial support for monitoring waterbirds from 2004 onwards was provided by Agencia de Medio Ambiente y Agua de Andalucía (Consejería de Medio Ambiente, Regional Government of Andalucía).

\section{BIBLIOGRAPHY}

AEMET. 2009. Generación de escenarios regionalizados de cambio climático para España. Agencia Estatal de Meteorología, Ministerio de Medio Ambiente y Medio Rural y Marino. Almaraz, P., Green, A. J., Agullera, E., Rendón, M. A. and Bustamante, J. 2012. Estimating partial observability and nonlinear climate effects on stochastic community dynamics of migratory waterfowl. Journal of Animal Ecology, 81: 1113-1125.

Alonso, C., Ménanteau, L., Rubio, J. C. and SERVATO, P. 2004. Una visión histórica de las salinas andaluzas. In, J. M. Fernández-Palacios (Ed.): Salinas de Andalucía, pp. 25-46. Consejería de Medio Ambiente, Junta de Andalucía. Sevilla.

Amat, J. A. 1981. Descripción de la comunidad de patos del Parque Nacional de Doñana. Doñana Acta Vertebrata, 8: 125-158.

Ashrenazi, S. and Yom-Tov, Y. 1996. Herons and fish farming in the Huleh Valley, Israel: Conflict or mutual benefit? Waterbirds, 19: 143-151.

Barbraud, C., Lepley, M., Mathevet, R. and Mauchamp, A. 2002. Reedbed selection and colony size of breeding Purple Herons Ardea purpurea in Southern France. Ibis, 144: 227 235.

BAYÁN, B. and DolZ, J. 1995. Las aguas superficiales y la marisma del Parque Nacional de Doñana. Revista de Obras Públicas, 3340: 17-29.

BirdLife InTERNATIONAL. 2004. Birds in Europe: Population Estimates, Trends and Conservation Status. BirdLife Conservation Series No. 12, Cambridge.

Burnham, K. P. and Anderson, D. R. 2002. Model Selection and Multi-model Inference: A Practical Information-theoretic Approach. Springer. New York.

CASAs, J. and URdiales, C. 1995. Introducción a la gestión hidráulica de las marismas del Parque Nacional de Doñana. In, C. Montes, G. Oliver, F. Molina and J. Cobos (Eds.): Bases Ecológicas para la Restauración de Humedales en la Cuenca Mediterránea, pp. 165-189. Consejería de Medio Ambiente, Junta de Andalucía. Sevilla.

Castroviejo, J. 1993. Memoria. Mapa del Parque Nacional de Doñana. Consejo Superior de Investigaciones Científicas, Junta de Andalucía. Madrid.

Chapman, A. and Buck, W. J. 1893. Wild Spain. (Spanish edition 1982: La España Agreste. La Caza). Ediciones Giner. Madrid. 
Chokri, M. A. and Selmi, S. 2011. Factors affecting colony size and reproductive success of little egret Egretta garzetta in the Sfax Salina, Tunisia. Waterbirds, 34: 234-238.

CoROMINAS, J. 1995. La agricultura en el entorno de Doñana. Revista de Obras Públicas, 3340: 65-74.

Dallinga, J. H. and Schoenmakers, S. 1987. Regional decrease in the number of white storks (Ciconia c. ciconia) in relation to food resources. Waterbirds, 10: 167-177.

De le Court, C. and Aguilera, E. 1997. Dispersal and migration in Eurasian spoonbills Platalea leucorodia. Ardea, 85: 193-202.

De le Court, C. and Feria, E. 2009. La Espátula en Andalucía. Bases para su Conservación. Manuales de Conservación de la Naturaleza $\mathrm{n}^{\circ}$ 5. Junta de Andalucía, Consejería de Medio Ambiente. Sevilla.

Den Held, J. J. 1981. Population changes in the purple heron in relation to drought in the wintering area. Ardea, 69: 185-191.

Fasola, M., Canova, L. and Saino, N. 1996. Rice fields support a large portion of herons breeding in the Mediterranean Region. Waterbirds, 19: 129-134.

Fasola, M., Hafner, H., Prosper, J., van der Koois, H. and Schogolev, I. V. 2000. Populations changes in European herons in relation to Africa climate. Ostrich, 71: 52-55.

Fasola, M., Rubolini, D., Merli, E., BoncomPAGNI, E. and BRESSAN, U. 2010. Long-term trends of heron and egret populations in Italy, and the effects of climate, human-induced mortality, and habitat on population dynamics. Population Ecology, 52: 59-72.

Feunteun, E. and Marion, L. 1994. Assessment of grey heron predation on fish communities: the case of the largest European colony. Hydrobiologia, 279/280: 327-344.

Fleury, B. E. and Sherry, T. W. 1995. Longterm population trends of colonial wading birds in the southern United States: The impact of crayfish aquaculture on Louisiana populations. Auk, 112: 613-632.

Frisch, D., Cottenie, K., Badosa, A. and GreEN, A. J. 2012. Strong spatial influence on colonization rates in a pioneer zooplankton metacommunity. PLoS ONE, 7: e40205.
García, L. V., Ramo, C., Aponte, C., Moreno, A., Domínguez, M. T., Gómez-Aparicio, L., Redondo, R. and Marañón, T. 2011. Protected wading bird species threaten relict centenarian cork oaks in a Mediterranean Biosphere Reserve: A conservation management conflict. Biological Conservation, 144: 764-771.

García-Novo, F. and Marín, C. 2006. Doñana: Water and Biosphere. UNESCO/Ministerio de MedioAmbiente. Madrid.

García-Novo, F., Martín, A. and Toja, J. 2007. La Frontera de Doñana. Universidad de Sevilla. Sevilla.

Garrido, J. R., Molina, B. and del Moral, J. C. 2012. Las Garzas en España, Población Reproductora e Invernante en 2010-2011 y Método de Censo. SEO/BirdLife. Madrid.

Geiger, W., Alcorlo, P., Baltanás, A. and MONTES, C. 2005. Impact of an introduced crustacean on the trophic webs of Mediterranean wetlands. Biological Invasions, 7: 49-73.

GonZÁlez, J. 1993. Las Marismas del Guadalquivir: Etapas de su Aprovechamiento Económico. C. P. Antonio Cuevas. Coria del Río.

HAFNER, H. 2000. Heron nest site conservation. In, J. Kushlan and H. Hafner (Eds.): Heron Conservation, pp. 201-217. Academic Press. San Diego.

Hafner, H., Pineau, O. and Kayser, I. 1994. Ecological determinants of annual fluctuations in numbers of breeding little egrets (Egretta garzetta L.) in the Camargue, S. France. Revue de Ecologie-La Terre et la Vie, 49: 53-62.

Kayser, Y., Girard, C., Massez, G., Chérain, Y., Cohez, D., Hafner, H., Johnson, A., SADOUL, N., TAMISIER, A. and ISENMANN, P. 2003. Compte-rendu ornithologique camarguais pour les années 1995-2000. Revue de Ecologie-La Terre et la Vie, 58: 5-76.

Kayser, Y., Gauthier-Clerc, M., Béchet, A., Poulin, B., Massez, G., Chérain, Y., Paoli, J., Sadoul, N., Vialet, E., Paulus, G., VincentMartin, N., Pilard, P. and Isenmann, P. 2008. Compte rendu ornithologique camarguais pour les années 2001-2006. Revue de Ecologie-La Terre et la Vie, 63: 299-349.

Kayser, Y., Walmsley, J., Pineau, O. and HAFNER, H. 1994. Evolution récente des effectifs de hérons cendrés (Ardea cinerea) et de 
hérons pourprés (Ardea purpurea) nicheurs sur le littoral français. Nos Oiseaux, 42: 341-355. Kloskowski, J., Green, A. J., PolaK, M., Bustamante, J. and Krogulec, J. 2009. Complementary use of natural and artificial wetlands by waterbirds wintering in Doñana, south-west Spain. Aquatic Conservation-Marine and Freshwater Ecosystems, 19: 815-826.

LEKUONA, J. M. 2002. Food intake, feeding behaviour and stock losses of cormorants, Phalacrocorax carbo, and grey herons, Ardea cinerea, at a fish farm in Arcachon Bay (southwest France) during breeding and non-breeding season. Folia Zoologica, 51: 23-34.

Macías, M., GreEn, A. J. and SÁnchez, M. I. 2004. The diet of the glossy ibis during the breeding season in Doñana, southwest Spain. Waterbirds, 27: 234-239.

MÁÑEZ, M. and GARRIDO, H. 1996a. Garcilla cangrejera Ardeola ralloides. Noticiario Ornitológico. Ardeola, 43: 240.

MáÑez, M. and Garrido, H. 1996b. Morito común Plegadis falcinellus. Noticiario Ornitológico. Ardeola, 43: 242.

MÁÑEZ, M., IbÁÑEZ, F., GARrido, H., EsPinAR, J. L., Del Valle, J. L., Chico, A., Martínez, A. and RoDRíGUEZ, R. 2010. Endangered waterbirds at Doñana Natural Space. In, C. Hurford, M. Scheneidr and I. Cowx (Eds.): Conservation Monitoring in Freshwater Habitats. A Practical Guide and Case Studies, pp. 357-373. Springer Netherlands. Dordrecht.

MáÑEZ, M. and Rendón-MARTos, M. 2009. El morito, la espátula y el flamenco en España. Población en 2007 y método de censo. SEO/ BirdLife. Madrid.

Martí, R. and Del Moral, J. C. 2003. Atlas de las Aves Reproductoras de España. Dirección General de Conservación de la Naturaleza y Sociedad Española de Ornitología. Madrid.

Mihoub, J. B., Jiménez, O., Pilard, P. and SARRAZIN, F. 2010. Challenging conservation of migratory species: Sahelian rainfalls drive first-year survival of the vulnerable lesser kestrel Falco naumani. Biological Conservation, 143: 839-847.

Mitsch, W. J. and Gosselink, J. G. 2000. Wetlands. John Wiley and Sons. New York.
MolinA, F. 1984. La pesca del cangrejo rojo americano y su influencia en el entorno del Parque Nacional de Doñana. Revista de Estudios Andaluces, 1984: 151-160.

Montesinos, A., Santoul, F. and Green, A. J. 2008. The diet of the night heron and purple heron in the Guadalquivir marshes. Ardeola, 55: 161-167.

Moser, M. E. 1984. Resource Partitioning in Colonial Herons, with Particular Reference to the Grey Heron Ardea cinerea L. and the Purple Heron Ardea purpurea $L$., in the Camargue, $S$. France. PhD Thesis. University of Durham.

NAGer, R. G., HAFner, H., Johnson, A. R. and CÈZILLY, F. 2010. Environmental impacts on wetland birds: long-term monitoring programmes in the Camargue, France. Ardea, 98: 309-318.

PANNeKoek, J. and VAN StRIEN, A. 2001. TRIM 3 Manual. (Trends and indices for monitoring data). Research paper no. 0102, Statistics Netherlands. Voorburg.

Perennou, C., Beltrame, C., Guelmami, A., Tomas-Vives, P. and Caessteker, P. 2012. Existing areas and past changes of wetland extend in the Mediterranean región: an overview. Ecologia Mediterranea, 38: 53-66.

Rendón, M. A., Green, A. J., Aguilera, E. and Almaraz, P. 2008. Status, distribution and long-term changes in the waterbird community wintering in Doñana, south-west Spain. Biological Conservation, 141: 1371-1388.

S antoro, S., Máñez, M., Green, A. J. and FigUerola, J. 2010. Formation and growth of a heronry in a managed wetland in Doñana, Southwest Spain. Bird Study, 57: 515-524.

Soriguer, R. C., RodríGuez, A. and Domínguez, L. 2001. Análisis de la Incidencia de los Grandes Herbívoros en la Marisma y Vera del Parque Nacional de Doñana. Organismo Autónomo Parques Nacionales. Madrid.

Tablado, Z., Tella, J. L., Sánchez-Zapata, J. A. and Hiraldo, F. 2010. The paradox of the long-term positive effects of a North American crayfish on a European community of predators. Conservation Biology, 24: 1230-1238.

Toral, G. M. 2011. Agricultura y Conservación en Doñana: La Importancia del Arrozal para las Aves Acuáticas. PhD Thesis. Universidad de Sevilla. 
Toral, G. M. and Figuerola, J. 2010. Unraveling the importance of rice fields for waterbird populations in Europe. Biodiversity and Conservation, 19: 3459-3469.

Toral, G. M., Stillman, R. A., Santoro, S. and Figuerola, J. 2012. The importance of rice fields for glossy ibis (Plegadis falcinellus): management recommendations derived from an individual-based model. Biological Conservation, 148: 19-27.

TortosA, F. S., MÁÑEZ, M. and BARCELl, M. 1995. Wintering white storks (Ciconia ciconia) in South West Spain in the years 1991 and 1992. Vogelwarte, 38: 41-45.

Tourenq, C., Bennetts, R. E., Sadoui, N., Mesleard, F., KAYSER, I. and HAFNER, H. 2000. Long-term population and colony patterns of four species of tree-nesting herons in the Camargue, South France. Waterbirds, 23: 236-245.
Wood, S. N. 2006. Generalized Additive Models: An Introduction with R. Chapman and Hall/ CRC. Boca Raton.

YounG, L. 1998. The importance to ardeids of the deep bay fish ponds, Hong Kong. Biological Conservation, 84: 293-300.

ZWARTS, L., BIJlsMA, R. G.., VAN DER KAMP, J. and WyMENGA, E. 2009. Living on the edge: Wetlands and birds in a changing Sahel. KNNV Publishing. Zeist.
Received: 2 May 2013

Accepted: 23 July 2013

Editor: Paola Laiolo 